\title{
Literacy Environments of Preschool Education Classrooms in Turkey: The Case of Muğla
}

\author{
Şeyda Deniz Tarım \\ Correspondence: Şeyda Deniz Tarım, Muğla Sıtkı Koçman University, Turkey
}

Received: July 13, 2015 Accepted: August 11, $2015 \quad$ Online Published: August 17, 2015

doi:10.11114/jets.v3i5.999 URL: http://dx.doi.org/10.11114/jets.v3i5.999

\begin{abstract}
This study examined the quality of the literacy environments of 17 public preschool classrooms in Muğla, Turkey through detailed observations using the OMLIT-CLOC, an inventory of classroom literacy resources that identifies and rates 11 aspects of the literacy environment on a scale from 1 (low) to 3 (high). The results indicated the literacy environments of preschool classrooms in Muğla-including print displays, books, writing and reading areas and listening materials - to be of low-to-moderate quality. Based on the findings of this study, other ways of improving preschool education classrooms can be pinpointed, such as enriching the book genres accessible to children, providing more supplementary print material in the classroom and integrating literacy materials, toys and props into other classroom learning centers.
\end{abstract}

Keywords: Emergent literacy, literacy environment, preschool education, Turkey

\section{Introduction}

This study is based on the social interactionist theory built upon cultural psychology (e.g., Vygotsky, 1978) that focuses on the culturally rich environments in which children live as mediators of learning (Tomasello, 1992). From this perspective, emergent literacy skills are understood as supported through social interaction with exposure to rich literacy materials (Sulzby \& Teale, 1991). In other words, what children learn may be affected by the literacy environment of their classroom (Guo, Justice, Kaderavek \& McGinty, 2012).

Recent studies pay crucial attention to the term "emergent literacy," defined as "the skills, knowledge, and attitudes that are presumed to be developmental precursors to formal reading and writing and the environments that support these developments" (Whitehurst and Lonigan, 1998, p. 849). Given their primary focus on social interaction, children who see their caregivers and teachers reading and writing around them will want to learn the letters and symbols required to interact with and imitate adults. This necessarily involves literacy; hence, the emergent literacy perspective acknowledges the importance of supportive environments for the development of early literacy skills (Whitehurst \& Lonigan, 1998).

The increasing emphasis on improving language and literacy standards has led researchers to focus on the characteristics of preschool literacy environments known to influence the development of children's early literacy skills (Whitehurst \& Lonigan, 1998; Neumann \& Roskos, 1993; Roskos and Neumann, 2001; Neumann \& Dickinson, 2001; Neumann, Hood, Ford \& Neumann, 2011; Neumann, Hood and Ford, 2013). Previous studies have documented that high-quality preschool programs assist children by providing them with meaningful literacy experiences within a literacy-rich environment (Wayne, DiCarlo, Burts \& Benedict, 2007).

\subsection{Emergent Literacy Environments}

Young children are often socialized into literacy by experiencing their environments. When classroom environments include rich literacy materials as learning opportunities and supportive adults who model and develop literacy skills and behavior by encouraging children to use these materials, their experiences in these environments become meaningful (Dunn, Beach, and Kontos, 1994, 2000; Neumann \& Roskos, 1993; Neumann \& Dickinson, 2001).

Studies examining the quality of preschool programs have established various dimensions of classroom environments to affect children's emergent literacy development, such as classroom organization, rich and appropriate literacy materials (Neumann \& Roskos, 1993; Wolfersberger, Reutzel, Sudweeks, \& Fawson, 2004) and literacy activities (Dunn, Beach, $\&$ Kontos, 1994). The literature has variously described high-quality literacy environment as comprising various 
essential dimensions including a distinct book area with a rich collection of books, writing and listening areas, considerable amount of print displays, literacy materials and toys distributed throughout the room (Neumann \& Roskos, 1993; Roskos \& Neumann, 2001; Neumann \& Dickinson, 2001).

Children's emergent literacy skills have been shown to be significantly affected by high-quality literacy environments that include a variety of children's books in accessible libraries and well-organized reading and writing areas (Justice, 2006; Neumann \& Roskos, 1993; Roskos \& Neumann, 2001; Vukelich, Christie, \& Enz, 2012). A study by Cunningham (2008) found that children who participate in a high-quality literacy environment have more positive attitudes towards reading. There is considerable research showing that providing children with informational books supports their academic vocabulary, knowledge of various concepts and listening comprehension skills (Chapman, Filipenko, McTavish, \& Shapiro, 2007; Kraemer, McCabe, \& Sinatra, 2012). In addition, Chapman et al. (2007) have found that both picture books and informational books facilitate children's reading motivation, attention and engagement.

An additional characteristic of literacy-rich classroom settings is that they provide children with considerable contact with print through the display of functional print materials (e.g., posters, signs and teachers' and children's writing samples) that provide children with examples of how spoken words can be represented in print (Justice, 2006). According to Neumann, Hood and Ford (2013), children instructed with environmental print showed higher print motivation immediately as well as 2 months after the intervention (which consists of adding literacy props to centers based on the needs and teacher mediation) when compared to students instructed with the same words in manuscript form and students who had no intervention. Their study shows that environmental print can be an effective tool for supporting letter-writing in young children and that drawing their attention to letters in environmental print can foster and sustain gains in a broad range of emergent literacy skills.

Literacy-rich classrooms also promote a variety of writing experiences by providing children access to different writing tools and materials (e.g., templates, tracing sheets) (Schickedanz \& Casbergue, 2009; Vukelich et al., 2012). Roskos, Christie, Widman, \& Holding (2010) reported direct linkages between children's access to print and writing materials and their literacy development.

\subsection{Context of the Study: Preschool Education in Turkey}

In Turkey, recent efforts to maintain and expand preschool education have reached many preschool-age children. Currently, about 40 percent of preschool-age children in Turkey currently attend preschool programs, in spite of the fact that preschool education is not compulsory. The annual growth observed in preschool attendance can be attributed to the many national-level initiatives to expand enrollment and provide high quality preschool education in Turkey. First and foremost are the steps taken by the Ministry of National Education (MoNE) to increase the coverage and improve the quality of preschool education as a national priority. However, these efforts are faced with certain challenges, such as the lack of systemic evaluation and enforcement of standards regarding the educational physical environment, curriculum and materials as well as teacher-training programs. A recent qualitative study by Göl-Güven (2009) evaluating the quality of early-childhood education classrooms in a randomly selected sample of public and private pre-primary schools in the Bakırköy district of Istanbul concluded that both public and private institutions had significant shortcomings, including a lack of physical space, furnishings, authoritarian teacher-child interactions and high teacher-student ratios. Another qualitative study conducted in the southeastern province of Kilis (Özgan, 2009) similarly encountered inadequate preschool physical conditions and facilities. The results of these studies suggest that the quality of preschool education in Turkey should be improved by developing national quality standards for preschool facilities and effective use of these facilities within the environment for better instruction.

Most research on the quality of preschool education in Turkey has focused on the physical space, furnishings and outdoor facilities of preschools (World Bank, 2013), with much less attention given to examining the dimensions of literacy environments. The lack of research into the pre-school literacy environment, including such areas as design, accessibility and display of literacy material, reflects the relatively lower priority given to developing language and literacy skills at the pre-school level.

Although pre-primary education classrooms in Turkey do not provide formal reading and writing instruction, considering that children's early literacy skills are an indicator of school readiness, their development should be supported before children enter primary school. Previous research has demonstrated that children require a rich physical literacy environment in order for their literacy skills to develop which (Roskos \& Neumann, 2001). Studies that increase the understanding of the quality of the literacy environment in preschool classrooms in Turkey are timely and warranted; therefore, the present study aimed to contribute to the literature by examining the quality of literacy environments in randomly selected preschools in the province of Muğla in the Aegean Region of Turkey. 


\section{Method}

\subsection{Participants}

This study was conducted with 17 randomly selected MoNE-affiliated public preschools in the central district of Muğla. After receiving official written permission from the MoNE provincial directorate, the researcher met with principals and teachers from the selected schools to explain the study objectives and the classroom observations involved in order to determine their willingness to participate in the study.

The safeguards to protect the identities of the schools and individuals participating in the study were also explained; namely: all data collected would be stored electronically in password-protected documents accessible only to the researcher; data would be shared only with students and other researchers for educational purposes; and no names or any other information that could be used to identify the schools or teachers involved would be used in any written report associated with this research.

After obtaining permission from principals and teachers, data was collected from 17 preschool classrooms in 17 preschools through classroom observations conducted by the researcher. Each preschool classroom was visited twice for approximately two hours per visit, during which time extensive field notes were taken.

\subsection{Data Collection Tool}

The OMLIT (Abt Associates, 2003) was developed as a battery of measures to address the need for reliable, research-based measurement of instructional practices and environmental support for language and literacy in the early childhood classroom (Goodson, Layzer, Smith, \& Rimdzius, 2004). The OMLIT includes six instruments: Classroom Description, Snapshot of Classroom Activities (SNAPSHOT), Read-Aloud Profile (RAP), Classroom Literacy Instruction Profile (CLIP), Quality Rating of Language and Literacy Instruction (QUILL) and Classroom Literacy Opportunities Checklist (CLOC).

This study was conducted using the OMLIT-CLOC, an inventory of classroom literacy resources that identifies and rates 11 aspects of the literacy environment on a scale from 1 (low) to 3 (high), as follows: Physical layout of the classroom (5 items); text or print environment (8 items); literacy-related materials and toys ( 2 items); books and reading area (12 items); listening area ( 3 items); writing supports (6 items); literacy materials outside of the reading and writing areas (3 items); diversity in literacy materials ( 3 items), instructional technology ( 2 items); richness of curriculum theme and integration of theme in classroom activities, materials, displays ( 7 items); and literacy resources outside of the classroom (4 items) (See Table. 1 below).

It is reported that nine of the ten sections of the CLOC had reliabilities above 70\% (three sections had agreement above $80 \%$ : writing resources $81 \%$, literacy toys and materials $82 \%$, and physical layout of classrooms $91 \%$ ) (Goodson, Layzer, Smith, \& Rimdzius, 2004).

Table 1. Classroom Literacy Opportunities Checklish Domains and Some of the Items

\begin{tabular}{|c|c|}
\hline Physical Layout of Classroom (5 items) & $\begin{array}{l}\text { Materials and objects in the room appear well organized (i.e., clearly } \\
\text { marked, sorted in a systematic way). The classroom layout allows children } \\
\text { to choose materials and participate in activities independently. }\end{array}$ \\
\hline Print Environment (8 items) & $\begin{array}{l}\text { Child names are matched with photografs of child/child and family or } \\
\text { representative object posted in classroom. Examples of functional print that } \\
\text { include words/letters or numerals are visible. }\end{array}$ \\
\hline Literacy Toys and Materials (2items) & $\begin{array}{l}\text { There are toys and/or materials accessible to children that include } \\
\text { words/letters and numerals (alphabet chart or rug is not counted here) }\end{array}$ \\
\hline Books and Reading Area (12 items) & $\begin{array}{l}\text { Total number of books in the classroom. There is a separate and distinct } \\
\text { reading area. }\end{array}$ \\
\hline Listening Area (3 items) & $\begin{array}{l}\text { There is an area for listening to recorded books and listening materials } \\
\text { accessible for children's use. }\end{array}$ \\
\hline Writing Supports (6 items) & $\begin{array}{l}\text { There is a separate writing area and writing materials accessible to } \\
\text { children. There are tools in the classroom accessible to children to help } \\
\text { them practice writing words/letters and numerals (e.g., stencils, templates). }\end{array}$ \\
\hline $\begin{array}{l}\text { Literacy Materials In Different Play Areas } \\
\text { (3 items) }\end{array}$ & $\begin{array}{l}\text { Literacy materials in dramatic play area. Literacy materials in other areas } \\
\text { (e.g., art, science, block area). }\end{array}$ \\
\hline in Literacy Mat & $\begin{array}{l}\text { Books/text materials accessible in the classroom show a variety of diverse } \\
\text { groups of people }\end{array}$ \\
\hline s) & Iren to use. \\
\hline Curr & $\begin{array}{l}\text { Classroom has a curriculum theme (e.g., not a truly content theme like a } \\
\text { color, a letter; common concepts like seasons; unusual concept like maps } \\
\text { or professions). Theme is evident in children's work on display (e.g., art, } \\
\text { writings) }\end{array}$ \\
\hline $\begin{array}{l}\text { Literacy Sources Outside of Classroom } \\
\text { (4 items) }\end{array}$ & $\begin{array}{l}\text { Book area/library outside of the classroom. Computer lab/computer room } \\
\text { or area outside of classroom. }\end{array}$ \\
\hline
\end{tabular}




\subsection{Data Analysis}

This is a qualitative study in terms of the type of data used and the descriptive analysis conducted. After each preschool classroom was observed, the classroom's literacy resources were rated on a 3 point scale (low to high) under the domains as mentioned in Table 1. The literacy environments of the preschool classrooms were assessed under 11 domains consisting of 55 total items.

Prior to the collection of data, inter-observer agreement was obtained using the observation measure, OMLIT-CLOC. Interrater reliability data for the OMLIT-CLOC were gathered throughout the data collection period on approximately $20 \%$ of the preschool classrooms. The author and the research assistant rated these classrooms' literacy environments. Percent agreement for the reliability checks (computed by dividing the number of agreements by the number of agreements plus disagreements) ranged from $82 \%$ to $90 \%$ all components of the measure.

\section{Results}

\subsection{Physical Layout of Classroom}

Almost half (8/17) of preschool classrooms were observed to have at least 2 distinct learning centers for different activities, almost one-third (6/17) had 3 or more distinct learning and the remaining (2/17) classrooms had no distinct learning center. The most common learning centers were dedicated to dramatic play, block play and art activities.

Further, in 9 classrooms most of the materials and objects appeared were clearly marked but in the remaining preschool classrooms (8/17), only few materials and objects appeared were clearly marked or sorted in a systematic way. While activity centers were labeled, not all of them were being used. For example, although most classrooms had an area labeled as a 'science and environment' activity center, the materials in these centers were not easily accessible by children, the materials were outdated, or, in some cases, there were no materials at all.

The majority (13/17) of preschool classrooms featured a layout designed to facilitate whole-group, small group and individual instruction. Almost every classroom included a large rug capable of accommodating all the children in the classroom, and most of the classroom layouts allowed children to choose some activities and materials; for example, low shelves and boxes used to store materials helped generate multiple possibilities for children to choose materials and activities on their own.

Less than a quarter (4/17) of the classrooms appeared to have insufficient space for the number of children in the classroom, inadequate lighting, or unpleasant odors. However, although the remaining 13/17 classrooms had enough space, they still appeared overcrowded, with materials stacked in such a way as to be inaccessible, and unpleasant odors were noted during the observations.

\subsection{Print Environment}

Only 2/17 classrooms displayed any examples of children's writings (i.e. actual letters or words, or lines, marks, or squiggles by children appearing to imitate formal letter-formation practices). Further, there were no examples of functional print such as posters with children's names matched to their photographs, family members or any representative object. In 10 classrooms, there was no functional print (print used for a purpose) with either words or letters visible. Although 7 classrooms featured calendars and written rules on display, in one of these classrooms, the calendar was above children's eye level (defined as the height of an adult's waist). Almost every preschool classroom (14/17) contained examples of functional print showing numerals (1-10); however, they were displayed so close to the ceiling that they were well beyond children's eye level. While the learning centers were labeled, there were no labels for toys or other stacks of material.

Similarly there were no environmental print such as posters with print or children's writings available in the classrooms. Only 5 classrooms has alphabet and numerals charts, but these charts were hung either high on the walls beyond children's eye level or behind cabinets so they were out of view.

\subsection{Literacy Toys and Materials}

Some classrooms (4/17) included 1-2 toys featuring words/letters and numerals, such as card and board games; however, children could not access these toys during their free play time. On rare occasions, they were able to use them after receiving permission from the teacher. None of the classrooms were observed to contain literacy materials such as magnets, stamps or flash cards with letters/numerals ${ }^{1}$.

\footnotetext{
${ }^{1}$ Under this domain, the materials which had numerals or letters were counted. Depending on the checklist, numeral charts or alphabet rugs or charts were not included.
} 


\subsection{Books and Reading Area}

All classrooms had more than 21 books, and all but 5 classrooms had a separate, distinct reading area containing books that children could choose from. However, these reading areas were modest, able to accommodate at most 2 children at a time. Reading areas were generally observed to be part of the circle area with a cabinet or basket of between 8-20 books close to the area, but the reading areas lacked soft furnishings such as pillows, cushions or couches that would render them more appealing.

Moreover, while the books accessible to teachers were in good conditions, most of the books accessible to children, unfortunately, were in relatively poor condition with torn pages, missing covers or faded print and included only one or two genres, usually stories or instructional books for cooking and toy-making. None of the booksacks contained poetry, science, history or other non-fiction magazines or books. Finally, the books accessible to children were not geared to a wide range of reading and comprehension levels from very easy to challenging.

\subsection{Listening Area}

None of the rooms were observed to have dedicated listening areas or material.

\subsection{Writing Supports}

All the classrooms were equipped with tables and chairs for children; however, they were used mainly for art activities and for lunch/snack time. There was no separate writing area with tables, chairs and writing materials accessible to children. In general, children who wanted to draw or color on their own used their own pencils and crayons, which were stored in cabinets.

Although classrooms were equipped with dry-erase boards and colored papers, children did not generally have the opportunity to use these materials outside of teacher-directed art activities.

Furthermore, there were no accessible tools (e.g., stencils, templates or tracing sheets) to help children practice writing words/letters and numerals. Classrooms also tended to lack writing materials as well as different methods (e.g. mailboxes, message boards) that could be used to help children practice writing for a purpose.

\subsection{Literacy Materials Outside of the Reading and Writing Areas}

Although each classroom included a dramatic play area with numerous examples of dramatic-play toys and materials, these did not include any literacy materials (e.g., notepad, phonebook, shopping list, pencil, magazine, or cookbook). Except for the books and reading area, none of the other centers contained books or any other literacy materials. Although 2 classrooms had captioned posters of the human body in the science area, these posters were above children's eye level. By contrast, puppets and other materials such as story boards to encourage storytelling were available in areas other than the dramatic-play area.

\subsection{Diversity in Literacy Materials}

Diversity among people (e.g., ethnic group, dis/ability) was not represented in any of the books, text materials or toys (e.g., clothing, food, decorative objects, dolls) accessible to children.

\subsection{Instructional Technology}

None of the classrooms had computers available to children, and only half of the classrooms had a laptop or desktop for the teacher's use (e.g. printing activity pages, preparing lesson plans).

\subsection{Curriculum Theme}

Because all MEB schools follow the same curriculum, the same curriculum themes were observed in all classrooms. During the weeks that the observations took place, curriculum themes included common concepts such as seasons and holidays as well as more unusual, rich concepts such as professions. Although not a true content, theme, classrooms also covered the concepts of colors, letters and numbers. These themes were evident in books read aloud by teachers and in art activities and songs; however, the themes were not always evident in classroom centers - for example, in charts, texts or posters - that might help children visualize and comprehend the concepts, and the books teachers read from were not accessible to the children for further reading alone or in shared-reading time with peers.

\subsection{Literacy Resources Outside the Classroom}

Only one of the classrooms observed had access to a library outside the classroom. However, despite its accessibility, this library was not visited by the children as a class during the observations. Moreover, the same preschool had a computer room outside the classroom, but it was only available to children during paid after-school activities.

\section{Discussion}

This study examined the quality of the literacy environments of 17 public preschool classrooms in Muğla through 
detailed observations using the CLOC inventory of classroom literacy resources. The results indicated the literacy environments of preschool classrooms - including print displays, books, writing and reading areas and listening materials - to be of low-to-moderate quality.

The relationship between curriculum and print environment is a major issue in preschool classrooms. Both these elements add powerful support to children's early literacy experiences and help ensure they become meaningful. However, the majority of classrooms observed within the scope of this study were found to have a fairly low-quality print environment, with very limited amounts of print material, such as text, children's writings (lines, marks or squiggles that appear to imitate print), functional prints (posters, charts, calendars) and labels (for toys or materials). Topics covered in the classroom curriculum were not reflected in easily identifiable text material such as read-aloud books or in teacher-produced posters or in children's own works. Although nearly half of the classrooms visited had alphabet or numeral chart, they were not at children's eye-level. These finding suggest that preschool classroom literacy environments can be improved by re-arranging literacy materials so they are more accessible to children.

Unsurprisingly, all the classrooms included sacks of books and reading areas; however, these areas, or the books in them, were in poor condition and unattractive to children. Indeed, none of the children were observed to show any interest in reading by picking up a book from the reading center and reading or pretending to read. The books available to children were mainly stories or narrative picture-books, with very limited choices of other genres such as information, concept books or poetry. These findings are in accordance with previous studies indicating that most books in preschool classrooms are narrative picture-books, not informational books (Chapman, Filipenko, McTavish, \& Shapiro, 2007; Justice, 2006; Kraemer, McCabe, \& Sinatra, 2012; Roskos \& Neumann, 2001; Vukelich, Christie, \& Enz, 2012) and suggest that in order to attract children's interests, reading areas need to be organized to be more physically and visually inviting to children and should be filled with a wider variety of book genres, including ones related to concepts covered in the curriculum.

In addition to reading areas, most classrooms included a dramatic play center and block play center; however, neither of these centers nor any other area outside the book/reading center contained any literacy materials or toys that could be used to enhance children's early literacy behaviors (e.g., a recipe book to look at while 'cooking'). Further, the results showed that there were no separate writing areas with writing materials available to the children to help them practice writing letters or numerals, or listening areas with recordings of books or any interactive technology that children could use. These findings were not entirely unexpected, considering that previous studies using a different literacy classroom observation scale (ELLCO) reported that many classrooms lacked literacy materials in different areas of the classrooms (Cunningham, 2008; Wayne, Dicarlo, Burst, \& Benedict, 2009). Based on these findings, it may be suggested that literacy materials should be embedded into different classroom activity centers in order to increase opportunities for children to engage in meaningful literacy behavior that can lead to future reading success.

Based on the findings of this study, other ways of improving preschool education classrooms can be pinpointed, such as enriching the book genres accessible to children, providing more supplementary print material in the classroom and integrating literacy materials, toys and props into other classroom learning centers.

In keeping with a social-interactionist perspective, a child's early literacy experiences should be understood as embedded within the context of their daily sociocultural environment. When classrooms are rich with literacy materials, young children can use these materials to engage in meaningful literacy activities and facilitate their literacy development (Roskos \& Neumann, 2001; Neumann \& Dickinson, 2001; Vukelich, et. al., 2012).

\section{Implications and Future Directions}

The rapid increase in the number of children entering preschool necessitates the establishment of clear standards that go beyond physical infrastructure in order to assure that all children in Turkey receive a quality pre-primary education. The literacy environment of the preschool classroom plays an important role in literacy development, as focusing on learning standards, particularly literacy experiences, skills and outcomes from an early age can contribute to the successful literacy development of children entering primary school.

This study extends support to the view that the essential aspects of the preschool classroom literacy environment include environmental and functional print displays, integration of literacy materials into activities and learning centers and ensuring that sufficient reading and writing materials are made accessible to children (Dunn, Beach, and Kontos, 1994, 2000; Neumann \& Dickinson, 2001).

Although this study provided valuable information on the current literacy environments of public preschool classrooms in Muğla, due to the small sample size, the results should not be generalized to the population at large. Future research should be conducted with larger national samples to compare the preschool classroom literacy environment in different parts of Turkey in order to formulate national standards that can improve the quality of literacy environments in 
classrooms throughout the country.

Furthermore, whereas the present study examined the physical aspects of preschool classroom literacy environments, future studies need to look at the psychological aspects of the literacy environment, in particular, how teachers interact with children and support their literacy development during classroom activities. Experimental studies are also needed to examine the long-term effects of interventions in the classroom literacy environment on children's literacy growth.

\section{Acknowledgement}

This study has been presented at the $7^{\text {th }}$ International Congress on Turkish Language Education and Teaching (UTEOK) in Turkey, in June 2014.

\section{References}

Cunningham, D. D. (2008). Literacy environment quality in preschool and children's attitudes toward reading and writing. Literacy Teaching and Learning, 12(2), 19-36.

Chapman, M., Filipenko, M., McTavish, M., \& Shapiro, J. (2007). First graders' preferences for narrative and/or information books and perceptions of other boys' and girls' book preferences. Canadian Journal of Education, 30, 531-553. http://dx.doi.org/10.2307/20466649

Dunn, L., Beach, S. A., \& Kontos, S. (1994). Quality of the literacy environment in day care and children's development. Journal of Research in Childhood Education, 9, 24-34. http://dx.doi.org/10.1080/02568549409594950

Dunn, L., Beach, S., \& Kontos, S. (2000). Supporting literacy in early childhood programs: A challenge for the future. In Roskos K. A., Christie J. F., (Eds.). Play and literacy in early childhood: Research from multiple perspectives (pp. 91-105). Mahwah, NJ: Lawrence Erlbaum.

Dickinson, D. K., \& Sprague, K. (2002). The nature and impact of early childhood care environments on the language and literacy development of children from low-income families. In S. Neuman \& D. K. Dickinson (Eds.), Handbook of early literacy research (pp. 263-280). New York: Guilford Press.

Dickinson, D. K., \& Tabors, P. O. (1991). Early literacy: Linkages between home, school, and literacy achievement at age five. Journal of Research in Childhood Education, 6(1), 30-46. http://dx.doi.org/10.1080/02568549109594820

Goodson, B. D., Layzer, C. J., Smith, W. C., \& Rimdzius, T. (2006). Observation Measures of Language and Literacy Instruction in Early Childhood (OMLIT). Cambridge, MA: Abt Associates, Inc.

Gol-Guven, M. (2009). Evaluation of the quality of early childhood classrooms in Turkey. Early Child Development and Care, 179, 4, 437-451. http://dx.doi.org/10.1080/03004430701217639

Guo, Y., Justice, L. M., Kaderavek, J. N., \& McGinty, A. (2012). The literacy environment of preschool classrooms: contributions to children's emergent literacy growth. Journal of Research in Reading, 35(3), 308-327. http://dx.doi.org/10.1111/j.1467-9817.2010.01467.x

Justice, L. M. (2006). Evidence-based practice, response to intervention, and the prevention of reading difficulties. Language Speech and Hearing Services in Schools, 37, 284-297. http://dx.doi.org/10.1044/0161-1461(2006/033)

Kraemer, L., McCabe, P., \& Sinatra, R. (2012). The effects of read-alouds of expository text on first graders' listening comprehension and book choice. Literacy Research and Instruction, 51, 165-178. http://dx.doi.org/10.1080/19388071.2011.557471

Neumann, S. B., \& Roskos, K. (1993). Access to Print for Children of Poverty: Differential Effects of Adult Mediation and Literacy-enriched Play Settings on Environmental and Functional Print Tasks. American Educational Research Journal, 30, 95-122. http://dx.doi.org/10.3102/00028312030001095

Neumann, S. B., \& Dickinson, D. (Eds.). (2001). Handbook of early literacy research. New York, N.Y.: Guilford.

Neumann, M. M., Hood, M., Ford, R. M., Neumann, D. (2011). Using environmental print to enhance emergent literacy and print motivation. Journal of Early Childhood Literacy, 12(3), 231-258. http://dx.doi.org/10.1177/1468798411417080

Neumann, M. M., Hood, M., \& Ford, R. M. (2013). Using environmental print to enhance emergent literacy and print motivation. Reading and Writing, 26, 771-793. http://dx.doi.org/10.1007/s11145-012-9390-7

Özgan, H. (2009). An Evaluation Related to Pre-school Education in Turkey. World Applied Sciences Journal, 7(3), 312-319.

Roskos, K., \& Neuman, S. B. (2001). Environment and its influences for early literacy teaching and learning. In S. B. 
Neuman \& D. Dickinson (Eds.), Handbook of early literacy research (pp. 281-294). New York: Guilford.

Roskos, K. A., Christie, J. F., Widman, S., \& Holding, A. (2010). Three decades in: Priming for meta-anakysis in play-literacy research. Journal of Early Childhood Literacy, 10, 55-96. http://dx.doi.org/10.1177/1468798409357580

Schickedanz, J., \& Casbergue, R. (2009). Writing in preschool: Learning to orchestrate meaning and marks (2nd ed.). Newark, DE: International Reading Association.

Sulzby, E., \& Teale, W. (1991). Emergent Literacy. In R. Barr, M. Kamil, P. Mosenthal, and P. D. Pearson (Eds.). Handbook of Reading Research Volume II (pp. 727-758). New York: Longman.

Tomasello, M. (1992). First Verbs: A case study of early grammatical development. Cambridge: Cambridge University Press. http://dx.doi.org/10.1017/CBO9780511527678

Wayne, A., Di Carlo, Cynthia F., Burts, Diane C., \& Benedict, J. (2007). Increasing the Literacy Behaviors of Preschool Children Through Environmental Modification and Teacher Mediation. Journal of Research in Childhood Education, 22(1), 6-16. http://dx.doi.org/10.1080/02568540709594609

Whitehurst, G. J., \& Lonigan, C. J. (1998). Child development and emergent literacy. Child Development, 69(3), 848-872. http://dx.doi.org/10.1111/j.1467-8624.1998.tb06247.x

Wolfersberger, M. E., Reutzel, D. R., Sudweeks, R., \& Fawson, P. C. (2004). Developing and validating the Classroom Literacy Environmental Profile (CLEP): A tool for examining the "print-richness" of early childhood and elementary classrooms. Journal of Literacy Research, 36, 211-272. http://dx.doi.org/10.1207/s15548430jlr3602_4

World Bank, (2013). Expanding and improving early childhood education in Turkey. Report No: 77723-TR.

Vukelich, C., Christie, J., \& Enz, B. (2012). Helping young children learn language and litearcy: Birth through kindergarten (3rd ed.). Boston, MA: Pearson.

Vygotsky, L. S. (1978). The development of psychological processes. Cambridge, MA: Harvard University Press.

\section{$(\mathrm{cc}) \mathrm{BY}$}

This work is licensed under a Creative Commons Attribution 3.0 License. 